\title{
The Legacy of Early Franciscan Thought
}

Edited by

Lydia Schumacher

DE GRUYTER 
ISBN 978-3-11-068241-0

e-ISBN (PDF) 978-3-11-068482-7

e-ISBN (EPUB) 978-3-11-068488-9

ISSN 0580-2091

DOI https://doi.org/10.1515/9783110684827

\section{(cc) BY-NC-ND}

This work is licensed under a Creative Commons Attribution-NonCommercial-NoDerivatives 4.0 International License. For details go to https://creativecommons.org/licenses/by-nc-nd/4.0/.

\section{Library of Congress Control Number: 2020944940}

\section{Bibliographic information published by the Deutsche Nationalbibliothek} The Deutsche Nationalbibliothek lists this publication in the Deutsche Nationalbibliografie; detailed bibliographic data are available on the Internet at http://dnb.dnb.de.

(C) 2021 Lydia Schumacher, published by Walter de Gruyter GmbH, Berlin/Boston Printing and binding: CPI books $\mathrm{GmbH}$, Leck

www.degruyter.com 


\section{Contents}

Acknowledgements — IX

Lydia Schumacher and Simon Maria Kopf

A Guide to Citing the Summa Halensis — XI

Abbreviations - XIII

Lydia Schumacher

Introduction - 1

\section{Part I: Philosophy and Theology}

Cecilia Trifogli

The Creation of Matter in the Summa Halensis - 15

Magdalena Bieniak

The Soul-Body Union in the Summa Halensis - 37

Anna-Katharina Strohschneider

The Summa Halensis on Theology and the Sciences: The Influence of Aristotle and Avicenna 49

Tiziana Suarez-Nani

On Divine Immensity and Infinity in Relation to Space and Time: The Crossroad of the Summa Halensis 71

Simon Maria Kopf

Providence in the Summa Halensis: Between Authority and Innovation -89

Oleg Bychkov

Suspended Beauty? The Mystery of Aesthetic Experience in the Summa

Halensis - 111

Lydia Schumacher

Free Will in the Summa Halensis 129

Nathalie Gorochov

Odo Rigaldus at the University of Paris (c.1220-48) - 151 
Alexander Fidora

The Talmud in the Summa Halensis - 169

\section{Part II: The Legacy of the Summa Halensis}

Jacob W. Wood

It's Not Just about Anselm: Aquinas' ST la, q. 2, ar. 1 and Early Franciscan Illumination Theory -185

Theo Kobusch

The Possible and the Impossible: Potentia absoluta and potentia ordinata Under Close Scrutiny -207

Richard Cross

The Metaphysics of the Incarnation in the Summa Halensis and its Place in the Later History of Christology — 221

Andrew V. Rosato

The Passions of the Will and the Passion of Christ in Franciscan Theology from the Summa Halensis to Duns Scotus - 239

Mary Beth Ingham, CSJ

Franciscan Identity, Poverty and the Rational Will: From Summa Halensis to John Duns Scotus 257

Volker Leppin

What is Later Franciscan Theology? Ockham and the Early Franciscans - 281

José Meirinhos

Intellectus agens triplex distinguitur: Early Franciscans and Avicenna in Petrus Hispanus' Theory of the Agent Intellect in the Scientia libri de anima - 297

William J. Short, OFM

Alexander of Hales in the Book of Conformities of Bartholomew of Pisa - 323

William J. Courtenay

Gabriel Biel and the Summa Halensis - 339

Riccardo Saccenti

The Reception of the Summa Halensis in the Manuscript Tradition until $1450-353$ 
Oliver Davies

Science, Philosophy and the Authority of the Early Franciscan Summa Halensis:

Learning from the Past for the Sake of the Future - 373

Contributor Biographies — 399

Index -405 



\title{
Intellectus agens triplex distinguitur: Early Franciscans and Avicenna in Petrus Hispanus' Theory of the Agent Intellect in the Scientia libri de anima
}

\begin{abstract}
The understanding of the nature and functions of the intellect became one of the main problems of the $13^{\text {th }}$-century Latin reception of Aristotle's De anima, which highlighted similar difficulties to those already felt by the Greek and Arab commentators in their struggle with those brief, laconic, cryptic pages where that faculty of the soul is discussed. Those early difficulties were increased by the reception of this theory in the already doctrinally-saturated vocabulary of the Augustinian tradition, where the demands of Christian theology and anthropology dominated the understanding of the soul-body relationship, perception, and the explanation of the activity of the rational soul as illumination. Petrus Hispanus' Scientia libri de anima addresses those difficulties with a long-winded theory of the faculties of the soul, which silently appropriates Avicenna's Liber de anima and other sources so as to explain human life, sensation, and knowledge. Here we discuss the explanation of the agent intellect, which allows us to observe how John of La Rochelle and Franciscan philosophy more generally inspired Petrus Hispanus' position.
\end{abstract}

Petrus Hispanus Portugalensis' Scientia libri de anima offers a detailed discussion of the human soul, its existence and faculties. ${ }^{1}$ The intellect is the key concept for understanding human knowledge and action. Treatise II, chapter 7 introduces a brief account of the agent intellect that seems eccentric in its time and cannot be found in Aristotle or in Greek and Arabic philosophers, who seem to be his main sources in other parts of this work.

\footnotetext{
Note: This paper is part of a research project on Petrus Hispanus - Instituto de Filosofia of the University of Porto (funded by Fundação para a Ciência e a Tecnologia, ref. UIDB/00502/2020). I want to thank Vitor Guerreiro and Rui Mesquita for the translation, and Lydia Schumacher for the invitation to contribute to this work and for her invaluable comments.
}

1 Pedro Hispano, Obras Filosóficas I: Scientia libri de anima, intro. and ed. Manuel Alonso Alonso (Barcelona: Juan Flors, 1961), henceforth Pedro Hispano, Scientia. I do not use the first edition Pedro Hispano, Scientia libri de anima, ed. Manuel Alonso (Madrid: CSIC, 1941), and, as the intellect is not directly addressed, I will not take in consideration the Commentary on the De anima attributed to Petrus Hispanus: Pedro Hispano, Obras Filosóficas II: Comentario al De anima de Aristóteles, ed. Manuel Alonso (Madrid: CSIC, 1944). 
In fact, the agent intellect is threefold: the first is the power of the creator, radiating [its light] above the human intellect, and illuminating itself as well as the things that come from it, which by itself it is impotent to reach. The second is the separate intelligence producing in the intellect certain revelations through the influence of its intervention. The third is the power of the intellectual soul included in itself, emanating from it, reducing the intelligible forms, imprinted in potency in the possible intellect, to the act of intellection, that is related to the presentation of intentions. ${ }^{2}$

In the next pages I want to discuss this threefold division of the agent intellect, which is intended as a defence of the human possibility of knowing, in three respective ways, the totality of intelligible beings. The author wants to assure the reader that 1. all knowledge possessed by the human soul is acquired; 2. all knowledge, properly so called, is certain and true in virtue of having been attained by unerring faculties or agents; 3. the whole of the intelligible realm can be known by the human intellect, including other and higher intelligent natures, which are not attained through perception. Thus, the agent intellect is the nexus not only of the human soul and the totality of intelligible and sensible forms, but also of the soul and the creator as the intelligent absolute cause of everything.

We can straightforwardly recognize here the claim that the human soul has not one but three intellective agents: God, the separate intelligence (or separate intelligences), and the individual agent intellect. In different ways, these intellects actualize the possibilities of intellection and the perfectibility or enhancement of the human soul: by illumination, by induction, and by abstraction. Petrus' detailed explanation of the human soul through the systematization of its faculties, which culminates in the domain of knowledge within this threefold division of the agent intellect, has textual antecedents that lead us in the first place to an Aristotelian problem and Avicenna's solution. But, for obvious reasons, we cannot find this division in any of those sources. As I will argue, it is John of La Rochelle who lurks in the background. If this is the case, we need to reassess the traditional interpretation of the doctrinal position of Petrus Hispanus' Scientia libri de anima and its date of composition.

Three main points will be discussed concerning the Scientia libri de anima: firstly, a general characterization of this ambitious handbook on the human soul; secondly, the theory of the agent intellect, on account of which this work was considered an exponent of the so-called 'Avicennized Augustinianism'; thirdly, I will propose to connect this theory and some other positions of Petrus Hispanus to John of La Rochelle's works on the soul. This leads at the end to an hypothesis on the dating of

2 Pedro Hispano, Scientia II.7 (ed. Alonso, p. 62, 13-21): 'Intellectus vero agens triplex distinguitur: primus virtus creatoris super intellectum humanum irradians ipsumque illuminans ei seipsum ac res ipsum excedentes, ad quarum capacitatem est inpotens declaratum. Secundus est intelligentia separata ei ex sui officii influentia quasdam revelationes inducens. Tercius virtus anime intellective sibi insita, ab ipsa emanans, formas intelligibiles in potentia intellectui possibili impressas ad actum intelligendi reducens, qui ad presentationem spectat intentionum' (my emphasis). 
this eclectic work, which stresses the direct influence exerted on it by early Franciscan thought on the soul.

\section{Petrus Hispanus' Scientia libri de anima as a Handbook}

The identity of this Petrus Hispanus Portugalensis is not of momentous importance for the present discussion, although it is hugely important in dating and contextualizing the Scientia libri de anima, where the author identifies himself as 'philosophicae sublimitatis gubernator, medicinalis facultatis decor ac proficue rector." ${ }^{3}$ The only proposed dating was by René-Antoine Gauthier, ${ }^{4}$ although this was not supported by arguments and took for granted the identity of this Petrus with the Portuguese Petrus Juliani, who became Pope John XXI in 1276, an identification that is far from well-documented. ${ }^{5}$

Apart from an overlooked reference by Nicolaus Antonius, in 1788, it was Martin Grabmann who, in 1928, made known the existence of the Scientia libri de anima in a Madrid manuscript. ${ }^{6}$ In 1937-38, Grabmann published a study of the possible intellect and the agent intellect in the Scientia, editing the three chapters of tractate X on

3 The colophon of the manuscript edited by Alonso reads: 'Ego igitur Petrus Hispanus Portugalensis liberalium artium doctor, philosophicae sublimitatis gubernator, medicinalis facultatis decor ac proficue rector in scientia de anima decrevi hoc opus praecipuum componendum.' Pedro Hispano, Scientia XII 8 (ed. Alonso, p. 498, 6-9).

4 René-Antoine Gauthier, 'Préface,' in Thomas Aquinas, Sententia libri de anima, in Opera Omnia XLI.1 (Rome: Commissio Leonina; Paris: Vrin, 1984), p. 241b: 'Pierre d'Espagne l'a sûrement écrite après avoir enseigné la médecine, sans doute au cours des séjours qu'il fit au Portugal entre 1250 et 1260.'

5 See José Meirinhos, 'Petrus Hispanus,' in Medieval Science, Technology and Medicine: An Encyclopedia, eds. T.F. Glick, S.J. Livesey, and F. Wallis (New York; London: Routledge, 2005), pp. 388-92; idem, 'Giovanni XXI, papa,' in Dizionario biografico degli italiani (Rome: Istituto dell'Enciclopedia Italiana, 2000), vol. 55, pp. 600-11. The traditional account identifying Petrus Hispanus and Petrus Iuliani/Pope John XXI can be read in Peter of Spain (Petrus Hispanus Portugalensis), Tractatus, Called Afterwards Summulae logicales, ed. Lambertus Marie de Rijk (Assen: Van Gorcum, 1972), pp. XXIV - XXLII.

6 Inter alia Martin Grabmann, 'Reciente descubrimiento de obras de Petrus Hispanus (Papa Juan XXI, d. 1277),' Investigación y Progresso 2 (1928), pp. 85-86; idem, 'Ein ungedrucktes Lehrbuch der Psychologie des Petrus Hispanus (Papst Johannes XXI. † 1277) im Cod. 3314 der Biblioteca Nacional zu Madrid,' Spanische Forschungen der Görresgesellschaft 1 (1928), pp. 166-73. Manuscript: Madrid, Biblioteca Nacional de España, MS 3314, ff. 3ra-67va, see José Meirinhos, Bibliotheca manuscripta Petri Hispani: Os manuscritos das obras atribuídas a Pedro Hispano (Lisbon: Gulbenkian, 2011), no. 351. After Alonso's editions, the work was discovered in another incomplete and anonymous manuscript: Paris, Bibliothèque nationale de France, 6433, ff. 77ra-123vb (text finishes at tr. IX, ch. 5); Meirinhos, Bibliotheca, no. 557. 
the intellect (5. possible intellect, 6 . agent intellect, 7. separate agent intelligence), ${ }^{7}$ so as to place its author in relation to 'Avicennized Augustinianism (augustinisme avicennisant)', a philosophical trend according to which Étienne Gilson had sought to group those Latin authors that identified the Augustinian illuminating God with Avicenna's Agent Intellect, explicitly conflating the two authorities. ${ }^{8}$ With the papers published by Gilson a decade earlier in hand, Grabmann emphasized the same conclusion reached by Gilson en passant: in 1277, Pope John XXI sparked the Parisian condemnation of Aristotelian positions, so as to uphold the 'Avicennized Augustinian' views he supposedly defended years before, in his own works on psychology and natural philosophy signed as Petrus Hispanus. ${ }^{9}$ Grabmann uses the Scientia as a proof that Petrus is simultaneously Avicennian on the possible intellect and the separate intelligence, and Augustinian on the agent intellect. ${ }^{10}$

It is under this doctrinal identification, highlighting the Avicennian presence in the theory of the intellect, that the work would come to be praised. It underwent two successive editions by the Spanish Jesuit and Arabist Manuel Alonso, ${ }^{11}$ which raised some interest mostly in the Iberian Peninsula (inter alia João Ferreira ${ }^{12}$ ). In History of Christian Philosophy in the Middle Ages, Gilson himself pays attention to this work for the first time, changing its doctrinal label but not the main conclusion. Gilson remarks that, 'Peter takes sides with the representatives of the Avicennian tradition.'13

7 Martin Grabmann, 'Die Lehre vom intellectus possibilis und intellectus agens im Liber de anima des Petrus Hispanus des späteren Papstes Johannes XXI,' Archives d'histoire doctrinale et littéraire du Moyen-Age 11 (1937-38), pp. 167-208, publishes tr. X, ch. 5-7 (intellectus possibilis; intellectus agens; intelligentia agente separata) and tr. XIII, ch. 8. The study itself is mainly a paraphrase on these texts.

8 Étienne Gilson, 'Pourquoi saint Thomas a critiqué saint Augustin,' Archives d'histoire doctrinale et littéraire du Moyen-Âge 1 (1926), pp. 5-127; idem, 'Les sources gréco-arabes de l'augustinisme avicennisant,' Archives d'histoire doctrinale et littéraire du Moyen-Âge 4 (1929/30), pp. 5-149; idem, 'Roger Marston, un cas d'augustinisme avicennisant,' Archives d'histoire doctrinale et littéraire du Moyen-Âge 8 (1933), pp. 37-42; see here p. 42 on both conditions that must be filled for one to be considered an adherent of this doctrinal position.

9 Gilson ('Les sources gréco-arabes,' pp. 106-7) quotes a short excerpt on the Avicennian theory of the two faces of the soul from Petrus' attributed commentary on the De animalibus discovered by Grabmann in another Spanish manuscript, and links its positions to the syllabus condemned by the pope in Paris in 1277. The commentary is now published in Peter of Spain, Questiones super libro De animalibus Aristotelis: Critical edition with introduction, ed. Francisca Navarro Sánchez (Farham: Ashgate, 2015); see XII, 10, pp. 291-93, which concludes that the intellect cannot know the First directly, but only by its effects, through abstraction.

10 Grabmann, 'Die Lehre vom intellectus possibilis,' pp. 173-74, 180; Grabmann identifies the author of the work with Pope John XXI, also asserting its relation to the 1277 Parisian condemnation (p. 181).

11 See n. 1. Alonso is silent on that question, not even mentioning Avicenna in the brief reference to sources, see Manuel Alonso, 'Introduction,' in Pedro Hispano, Obras Filosóficas, p. XLVI.

12 João Ferreira, Presença do augustinismo avicenizante na teoria dos intelectos de Pedro Hispano (Braga: Editorial Franciscana, 1959).

13 Gilson, History of Christian Philosophy in the Middle Ages (London: Sheed and Ward, 1955), p. 320. 
While acknowledging that it is not highly important to know whether we should call this doctrinal complex 'Augustinian' or give it some other name, what seems to him more relevant is that 'one of its most typical representatives, Peter of Spain, happens to be the pope who, under the name of John XXI, would later bring about the condemnation of 1277. ${ }^{14}$ And mostly he stresses that, even if not identifying the separate agent intelligence with the God of St Augustine, 'he states its existence and its illuminating functions just as they are described in Avicenna,' ${ }^{15}$ and hence, Gilson coined a new and unique label for the work: 'To our personal knowledge, this is the only known case of straight Latin Avicennism. ${ }^{16}$

In the last edition of La philosophie au XIIIe siècle, Fernand van Steenberghen adds yet another suggestion to this kind of labelling competition: 'Quant à l'orientation doctrinale du traité, on y trouve un aristotélisme teinté d'augustinisme et d'avicennisme.' ${ }^{17}$ And nothing more is said on the work's doctrinal position, which Steenberghen considered 'une véritable somme de psychologie, le plus ancien exposé systématique de la psychologie aristotélicienne, ${ }^{, 18}$ but without suggesting a context or a date of composition.

What we see in these studies is that the chapter on the separate agent intelligence $(\mathrm{X}, 7)$ seems to be taken as a unique identifier of the work, in a decontextualized way that ignores the much more nuanced theory of the human intellect that Petrus proposes.

The general Avicennian tenor of the work, in fact not limited to the question of the intellect, has been straightforwardly confirmed by the detailed analyses devoted to the Scientia by Dag Hasse in his Avicenna's De anima in the Latin West. Upholding the dating proposed by Gauthier, Hasse echoes in fact Gilson's last word when stating that the Scientia is 'perhaps the most Avicennian work written in the West, ${ }^{, 19}$ which belongs to the final period of Avicenna's influence among the Latins. ${ }^{20}$

14 Gilson, History of Christian Philosophy, p. 323.

15 As we shall see, this separate Agent Intelligence has not exactly the same function as in Avicenna. 16 Gilson, History of Christian Philosophy, pp. 681-82, n. 44. It must be noted that in none of his studies did Gilson consider Petrus Hispanus as an Augustinian Avicennist, as in fact he fails to meet both criteria to be one of them (he accepts a limited role for God as agent intellect and never quotes Augustine and Avicenna as his source).

17 Fernand van Steenberghen, La philosophie au XIIIe siècle (Louvain-La-Neuve: Peeters, 1991), pp. 138-40, section devoted to 'La littérature philosophique à Paris,' even if nothing is said or confirmed about the place of composition of this work. A short paragraph is dedicated to the Scientia, pp. 139-40: 'As regards the doctrinal orientation of the treatise, one finds there an Aristotelianism tainted by Augustinism and Avicennianism.'

18 Steenberghen, La philosophie au XIIIe siècle, p. 136.

19 Dag Nikolaus Hasse, Avicenna's De anima in the Latin West: The Formation of a Peripatetic Philosophy of the Soul, 1160-1300 (London: The Warburg Institute, 2000), p. 55: 'The Scientia libri de anima, dating between 1250 and 1260, is perhaps the most Avicennian work written in the West.' It is a work that 'is most heavily indebted to Avicenna's De anima' (p. 59).

20 On the decline of the influence of Avicenna's Liber de anima in the West, see Dag Nikolaus Hasse, 'Aristotle versus Progress: The Decline of Avicenna's De anima as a Model for Philosophical Psychol- 
The study of the work around one doctrinal point overshadowed all its other unique features, some of which include its structure, omission of sources, style and peculiar mode of exposition, extensiveness, and detailed classification of faculties. Steenberghen and Gauthier had very judiciously concluded that the author 'entreprend de faire le point des connaissances de son temps sur l'âme, ${ }^{21}$ in the words of Gauthier. Right from the Prologue, Petrus Hispanus is quite explicit, stating that in this work he wishes to present 'the sentences of truth about all questions' on the soul, in a compendious and thorough exposition (compendiosam ac perfectam [...] traditionem), dispensing with research discourses or disputes, which he claims to have already published elsewhere. ${ }^{22}$ Consequently, he forgoes the discussion of other authors' positions on each issue; wishing simply to state, in true and unambiguous sentences, a complete knowledge (perfecta notitia) of the soul. ${ }^{23}$ Henceforth, he offers a personal work, silently compiling from others, not only avoiding questions and further discussion of opposing positions, but also reducing arguments, for the sake of providing classifications and divisions, definitions, and examples. At the end of the blazing colophon describing his career (see n. 3), he reiterates that he made this 'excellent book componendum' (in scientia de anima decrevi hoc opus praecipuum componendum), that is, with materials drawn from other authors. Since he is only interested in scientia and not in authority, he refrains, in the whole work, from quoting any authority. However, this is not to say he does not paraphrase or literally quote sources, Avicenna among them. Dag Hasse identified more than 110 quotations from Avicenna's Liber de anima, from all parts of the work on a massive scale, ${ }^{24}$

ogy in the Latin West,' in What is Philosophy in the Middle Ages?, eds. J.A. Aertsen and A. Speer, Miscellanea Mediaevalia 26 (Berlin; New York: De Gruyter, 1998), pp. 871-80. Avicenna's 12th-century Latin translation is published in Avicenna Latinus, Liber de Anima seu Sextus de Naturalibus, 2 vols, ed. Simone van Riet (Leuven: Peeters, 1968-72).

21 Gauthier, 'Préface,' in Thomas Aquinas, Sententia libri de anima, 241*: 'Undertakes to take stock of the knowledge of the soul from his time.' (Trans. Schumacher)

22 Pedro Hispano, Scientia, Prologue 5, 7-13: 'Ad nostrae igitur thronum mentis curiosa necnon executione digna ascendit intentio, ut de natura animae differentiarumque eius compendiosam ac perfectam ordinaremus traditionem, ut, postquam sermones inquisitivi sub disputationis examine procedentes in aliis operibus a nobis editis sint praemissi, in hoc ergo negotio omnium inquisitionum veritatis sententiae certis summis ac brevibus concludantur;' translated in Hasse, Avicenna's De anima, pp. 57-58: 'Hence the inquisitive intention, which is worth pursuing, arose to the throne of our mind that we should provide a comprehensive and perfect account of the nature of the soul and its differences, so that after investigative discourses proceeding under the examination of the disputation [method] had been published by us in other books and had been sent out in advance, in this work the sentences of truth about all questions are brought.'

23 Petrus Hispanus, Scientia, Prologue 5, 14-28.

24 Hasse, Avicenna's De anima, pp. 59-60. See n. 274: 'The quotations come from the following chapters of Avicenna's De anima (the number of quotations is given in brackets after the chapter number): I,1 (1); I,4 (3); I,5 (37); II,1 (3); II,2 (2); II,3 (13); II,4 (9); II,5 (2); III,3 (1); III,4 (1); IV,1 (12); IV,2 (1); IV,3 (7); IV,4 (3); V,1 (2); V,2 (1); V,3 (1); V,5 (3); V,6 (8); V,8 (2).' All these quotations are identified in the Index locorum, pp. 234-314. 
which are used tacitly as Petrus' own teaching, concluding that, 'Avicenna's philosophy is integrated into the Scientia to such an extent that there is hardly a single chapter in Avicenna's book which is not quoted or somehow adopted by Petrus. ${ }^{25}$

The work's structure also reveals its sources. It is neither a paraphrase of Aristotle's De anima, nor does it follow that work's structure. The main structure coincides with Avicenna's Liber de anima. The content is briefly summarized in Scientia's prologue. ${ }^{26}$ The first tractate is on the essence and existence of the soul (tr. I = Avicenna's I,1-4); the second contains a summary of the faculties to be discussed (tr. II = I,5); then the author devotes three treatises, respectively, to each one of the three main parts of the soul (tr. III - XI = II,1 - V,6), while the last two are dedicated to the same subjects of the final chapters in Avicenna's Liber de anima: the distinction of the organs (tr. XII $=\mathrm{V}, 8$ ) and the opinions of ancient authors on the soul (tr. XIII = V,7). Throughout the Scientia content and subject matter are added from other authors, none of whom are quoted by name. For each topic discussed, Petrus seeks to reach a definition, sometimes after lengthy inquiry, while drawing on different sources. As he avoids the presentation of different positions, in this regard, his work certainly does not take as a model any of the works on the soul by John of La Rochelle, who in the Tractatus de divisione multiplici potentiarum animae $(c .1233-35)^{27}$ and in the Summa de anima $(c .1235-36)^{28}$ devotes considerable space to the different theories of the soul and its faculties (less in the Summa than in the Tractatus). By examining the details of this work, we will verify that John of

25 Hasse, Avicenna's De anima, p. 59. On the next page, Hasse describes the preferred and the ignored Avicennian theories: 'he is not interested in Avicenna's more theoretical discussions of the notions of substance, form and perfection, or the Flying Man (1,1-3); he quotes almost every page of Avicenna's account of the faculty of touch $(11,3)$, but makes fewer use of the chapters on the other senses and very few of the third book on vision he is interested in the internal senses, but leaves out the theories of dreams, sleep and waking, prophecy and divination (IV,2 and IV,4), which belong to the Parva naturalia tradition; and he adopts theories on the intellect, but not the discussions of the incorporeality, individuation and immortality of the soul (V,2-4).' (Hasse, ibid., p. 60). In fact, Petrus discusses some of these Avicennian theories, but not in the expected places, as is the case for the 'Flying Man argument,' in an original move used as an argument for the existence of an internal speech of the soul; see José Meirinhos, Metafísica do homem: Conhecimento e vontade nas obras de psicologia atribuídas a Pedro Hispano (século XIII) (Porto: Afrontamento, 2011), pp. 193-97. 26 Pedro Hispano, Scientia, Prologue 5, 14-20: 'In hac igitur sciencia tradetur perfecta notitia substantie anime, differentiarum, virtutum, operum, proprietatum et omnium dispositionum, que ei insunt ex natura propria et corporis subiecti, et procedet hystoria circa animam intellectivam separatam et circa eius perpetuam et inmortalem existenciam et organorum distinctiones assignabuntur. Antiquorum vero opiniones in fine operis proferentur' (my emphasis).

27 John of La Rochelle, Tractatus de divisione multiplici potentiarum animae, ed. Pierre MichaudQuantin (Paris: Vrin, 1964).

28 John of La Rochelle, Summa de anima, ed. Jacques-Guy Bougerol (Paris: Vrin, 1995). 
La Rochelle is a main guide on the appropriation of Avicenna ${ }^{29}$ and a literal source of many ideas and definitions. ${ }^{30}$

Petrus offers a more symmetric structure than Avicenna and organizes the science of the soul around three main questions: the substance of the soul, comprising the discussion of its existence and essence; the description of the soul's faculties; and the relation of the faculties to its organs and objects. These are also the main subjects of John of La Rochelle's Tractatus and Summa de anima, which Petrus emulates in the treatises devoted to the sensitive and intellective faculties (the first tractate of each set deals with the proper essence and existence of each one). And, perhaps inspired by the treatise on the human being in the Summa fratris Alexandri, ${ }^{31}$ or other theological works on the soul, he adds, for the sensitive and the intellective souls, separate tractates on their active faculties (respectively, treatises VIII and $\mathrm{XI}$ ), including the discussion of free will and happiness, ${ }^{32}$ but omitting biblical or explicitly religious questions.

\section{The Question of the Threefold Agent Intellect}

Cognition and volition are explained by 13th-century authors as the output of a variable number of soul's faculties. The threefold agent intellect theory is the locus of the possibility of knowledge. Re-reading Petrus as quoted above, some questions must be raised: why is a threefold agent intellect necessary? How does it relate to the individual human soul? Is this an original doctrine from Petrus Hispanus? How is it justified and developed in the Scientia? Is there a discussion on how the three agents and the corresponding kinds of mental content interact? Are there non-cognitive consequences of this threefold division of the agent intellect?

Ever since Aristotle's laconic and obscure statement on the agent intellect in $D e$ anima III.5, that brief chapter has never ceased to fascinate, not only for the possibilities it opens up for a cogent explanation of true human knowledge, but also for the host of difficulties that the division of the intellect into passive and active powers raises. The history of the problem and the different solutions proposed by

29 On Avicenna in John of La Rochelle's works on the soul and in the Summa Halensis, see Hasse, Avicenna's De anima, pp. 47-54; on Avicenna's psychological ideas that will be influential in early Franciscan theories of knowledge, see Lydia Schumacher, Early Franciscan Theology: Between Authority and Innovation (Cambridge; New York: Cambridge University Press, 2019), pp. 68-75.

30 As an example, Petrus Hispanus' chapter on the definitions of the soul is excerpted from John's Tractatus, collecting 11 different definitions; see Meirinhos, Metafisica do homem, pp. 66-71.

31 Alexander of Hales, Doctoris irrefragabilis Alexandri de Hales Ordinis minorum Summa theologica (SH), 4 vols (Quaracchi: Collegium S. Bonaventurae, 1924-48), Vol II, In 4 ('De homine'), pp. 384784.

32 The tendency to add the discussion on free will is apparent in other Latin psychological works on the soul, as in John Blund, Treatise on the Soul, eds. Daniel A. Callus and R. W. Hunt, intro. and trans. Michael W. Dunne (Oxford: Oxford University Press, 2013), ch. 26, pp. 212-28. 
Greek, Arabic and Latin commentators still need to be retraced step by step. ${ }^{33}$ It is one of those stages, characteristic of the Latin reception of Aristotle in the first half of the 13th century, which Petrus Hispanus here presents in epitome, as part of a broader theory of the human knowledge and its relation with what exists.

To my knowledge, this tripartite division of the agent intellect is not expressed in such clear terms by any other author. Even Petrus, when explaining how the intellect works (in chapters 5, 6 and 7 of treatise X), does not repeat it in the same concise manner, ${ }^{34}$ even if these three chapters must be read as its development in the framework of a general explanation of human knowledge. In itself knowledge is the union of the receptive power with a received content, insofar as they are proportionate. This is the reason why only spiritual substances, totally deprived of matter, can know as they can receive all the forms. In Petrus' wording, knowledge is the actualization of a capacity to receive the forms of external things by abstraction. ${ }^{35}$

Concerning knowledge, after having expounded the workings of sense perception, Petrus Hispanus mainly follows the Avicennian theory of the five inner senses to explain abstraction from sensation and the formation of intentions of non-sensible things. ${ }^{36}$ Being the operation of a sensible capacity, and as their objects are sensible forms, at this level there is not yet knowledge. Regarding knowledge of the material things, the soul is purely potential, as a tabula rasa with no signs as yet inscribed upon it. Representations or images generated through perception are received by the possible intellect, but they require a capacity in act, the agent intellect, in order to become actually known, that is to say absolutely deprived of their individual, material and sensorial markers. ${ }^{37}$

However, Petrus does not confine the human intellect to knowledge by abstraction of the potentially intelligible forms and the intentiones received from the internal senses. The intellect, being immaterial and in act, is in its turn able to know by its

33 Jean Jolivet, 'Étapes dans l'histoire de l'intellect agente,' in Perspectives arabes et médiévales sur la tradition scientifique et philosophique grecque, eds. Ahmad Hasnawi, Ali Elaramni-Jamal, and Maroum Aouad (Leuven: Peeters, 1997), pp. 569-82.

34 In treatise II, Petrus offers in 12 chapters a general and condensed presentation of all the faculties of the soul. After this presentation 'secundum viam generalem' (p. 43) he goes to detail each one through 'sermones speciales' (p. 77) in treatises III to XI. There is no exact coincidence in the classification of the faculties of the soul in these two parallel approaches. This is probably a consequence of the incomplete harmonization of the sources employed.

35 Pedro Hispano, Scientia, VI, 3-4 (sensible apprehension and abstraction); X, 2 (intellectual substance and cognition).

36 On external perception and the five senses: tr. II, 4 and VI. On the five internal senses 'sensus communis, ymaginatio, ymaginativa, estimatio et memoria:' tr. II, 5 and VII. On knowledge and on what follows about intelligent substances, see Meirinhos, Metafísica do homem, pp. 105-9.

37 Pedro Hispano, Scientia, X, 6 (ed. Alonso, p. 379, 3-10): 'Intellectiva vero anima omnium rerum ex perceptionis actu capax cunctarum effigierum est receptiva et ideo ad sui perfectionem duplici eget virtute possibili et agenti. Nam cum ipsa ad omnium intelligibilium obiectorum susceptionem habeat potestativam aptitudinem, que ex seipsa ad actus non deducitur, exigit virtutem activam, que obiecta ad actum operationis et virtutem susceptivam ad actum perceptionis perducit.' 
own powers other intelligible natures unattainable by sense perception. This is evidently a non-Aristotelian addition, legitimized by some Neoplatonist commentators. Petrus' argument is twofold and necessitarian: the intellect was created in order to understand the totality of what there is, and, as an intelligent nature, it could not but know whatever there is that may amount to knowledge. What the possible intellect receives from the imagination becomes universal knowledge when actualized by an agent capacity, which concludes the process of abstraction. The higher intellectual entities, absolutely deprived of sensible parts, are unavailable to the senses, but, in virtue of their intelligible nature, they act directly on the intellect, through its active power, by illumination or inducing the forms in itself. In order to know these different kinds of entities, the human intellect requires the help of different proportionate agents. Hence the intellect's three agents mentioned above. ${ }^{38}$ The first one is the power of the creator (virtus creatoris), sometimes designated in the text as Intelligentia prima or by other names that bring out its primacy; as a pure intellectual being it radiates light over the human intellect, illuminating itself and the realities that exceed the intellect, thus making them knowable. The separate intelligence, which is here mentioned as a singular intelligentia separata, ${ }^{39}$ but in several other passages is suggested to exist in greater number, induces revelations in the agent intellect. ${ }^{40}$ And the lower agent is the active power proper to the human intellect, being connatural to the intellect itself (virtus anime intellective sibi insita, ab ipsa emanans). This one actualizes the intelligible forms, imprinted in potency upon the possible intellect, and by its nature is by itself knowable.

This hierarchy of agents present in human intellection is in accordance with the hierarchy of really existent intelligent substances. ${ }^{41}$ The first substance, that creates everything, knows everything as its cause and through exemplar forms in itself, without reception of sense data, by presence and without diversity. The second intelligence(s) knows through contemplation in the light of the first one and, by its nature, can represent the intelligible things. And finally, the intellect knows everything by the reception of species from external things and, being deprived of organs, needs the contribution of the internal and external senses and the abstraction of the perceived corporeal forms to achieve knowledge.

38 See n. 2. On the presentation of the threefold agent intellect theory and its origin in John of La Rochelle, I summarize with some additions Meirinhos, Metafísica do homem, pp. 133-46.

39 It must be noted that the name intelligentia agens separata is only used in the tabula of treatise $\mathrm{X}$ (ed. Alonso, p. 345, 27) and in the marginal title of the chapter itself (ed. Alonso, p. 385, 1-2). In the text the name 'intelligentia separata' is used; see also p. 385, 21, etc.

40 Some examples are provided here, with the caveat that the name in each case can stress different aspects or entities: 'primas intelligentias' (I, 4; ed. Alonso, p. 34, 1), 'intelligentie increate' (VI, 2; ed. Alonso, p. 156, 6), 'intelligentias creatas' (V, 1; ed. Alonso, p. 156, 7-8) 'intelligentia secunda' (VI, 3; ed. Alonso, p. 161, 8), 'intelligentie' (IX, 3; ed. Alonso, p. 309, 10), 'separate intelligentie’ (X, 6; ed. Alonso, p. 384, 25, and XI, 1; ed. Alonso, p. 432, 3).

41 Pedro Hispano, Scientia, VI, 3 (ed. Alonso, p. 161, 3-18). 
The threefold agent in human intellection is in harmony too with the threefold order of things that can be known, ${ }^{42}$ each one in correspondence with one sort of agent, a perfect homology between the intelligibles and the intellectual powers, both distributed on three levels. ${ }^{43}$ The dispositions of the first essence concern the creator of everything: they are beyond the human intellect (super intellectum sunt), and, since the intellect cannot elevate itself to them, it requires extrinsic illumination (extrinseca perlustratione indiget). The separate created essences, to which the human intellect is elevated with the aid of the created intelligences themselves. And the inferior things, whose representations come from perception, for whose knowledge the action of the human intellect suffices.

The triple cognitive agent power of the human soul mirrors ${ }^{44}$ precisely the posited order and ontological diversity of all knowable entities. Since the human intellect is like a blank page, the corresponding agents are required to generate or receive the intelligible forms. Even more important is the upshot of the enumeration: in all and each one of these acts, the presence of the agent intellect is required. The agent intellect is a feature present in any individual human soul, which needs all three agents to achieve its end, the knowledge of all kinds of knowable natures.

This grounds an optimistic epistemology, according to which everything the world comprises can be properly received and known by the human intellect. The confidence in the creator of everything is the master principle of the organization and the coherence of science, as a cognitive mirror of nature. This runs as a series of assumptions supporting each other. Everything was created by an intelligent being, and thus everything is intelligible, so there must be a high created capacity with all that is necessary to acquire knowledge of everything. The science of the soul is devoted exactly to explaining how this capacity is structured.

When elaborating on knowledge, in treatise X ('De virtutibus intellectivis apprehensivis'), Petrus Hispanus devotes successive chapters to the possible intellect

42 See pseudo-Augustine (Alcher of Claraval?), De spiritu et anima 4 (PL 40:781-82): 'Per rationalitatem habilis est illuminari ad aliquid cognoscendum infra se et supra se, in se et juxta se. Cognoscit siquidem Deum supra se, et se in se, et angelum juxta se, et quidquid coeli ambito continetur infra se.' This is quoted by John of La Rochelle, Tractatus de divisione, II.15, 83; idem, Summa de anima, II.4, c. 63, 191.

43 Pedro Hispano, Scientia, X, 7 (ed. Alonso, p. 386, 19-29): 'Rerum vero triplex ordo distinguitur. Primus est rerum ad dispositiones prime essentie omnium conditoris spectantium, que super intellectum sunt, ad quas vero, ad ipsum et eius proprietates cum intellectus nequeat elevari, eius extrinseca perlustratione indiget. Secundus est rerum comparium ad factas separatas essentias spectans, ad quas ex create intelligentie officio elevatur. Tertius in infimis rebus consistit, ad quarum conprehensionem eius sufficit industria. Sed in hiis omnibus operibus agentis virtutis interne officium necessarium est' (my emphasis). Another presentation of the three kinds of objects of the agent intellect: Scientia, X, 6 (ed. Alonso, p. 384, 2-16). See also Ferreira, Presença do augustinismo avicenizante, pp. 43-44. 44 The intellect is a speculum mundi that fulfils itself in the contemplation of all the archetypes, 'in rerum omnium exemplarium contemplatione perfecitur ad instar speculi mundi' (Scientia, X, 6, ed. Alonso, p. 380, 18-22). 
(ch. 5), the agent intellect (ch. 6), and the separate agent intelligence (ch. 7). As regards active powers, only the agent intellect and the separate agent intelligence are actually and separately discussed. The author did not intend to wholly adopt the Avicennian theory of the intellect, but instead integrates it in a comprehensive theory of the threefold agent intellect. However, Petrus does not reserve a chapter for treating the illumination by the first intelligence, or the creator. Some questions can be raised about the meaning of such an absence: does illumination through the first intelligence not belong to intellectual apprehension? Is it outside philosophical enquiry? We can surmise this union with the creator as love pertains properly to the volitional soul, where we can find a dedicated capacity of the soul for innate desire and ascent to the creator of all things: theophilosia. ${ }^{45}$

There is no room for doubt that the Prima intelligentia is the creator of all things, ${ }^{46}$ whether in its role of producer ex nihilo of all there is, or in its function as the light of the human intellect. There is no confusion here with the Intelligentia agens separata, a created second intelligence (or a set of intelligences) that can be an agent of the human intellect, alongside the first intelligence and the proper agent of the intellect. This is clear in the explanation of the agent intellect who: 1. illuminates by its own light the intelligible species received in possible intellect from the sensitive potencies; ${ }^{47}$ 2. as it was created to know the supreme cause by turning to it its face, only in this act achieves its highest end; ${ }^{48}$ and 3. also contemplates the separate substances to which it conforms, and thus the separate substances manifest to the

45 'Theophilosia' is an active intellectual faculty above synderesis, mentioned only by Petrus Hispanus and just once. See Scientia, XI, 7 (ed. Alonso, p. 442, 21-22); cf. José Meirinhos, 'De l'intellect à la Theophilosia: La plus haute réalisation de l'âme chez Petrus Hispanus Portugalensis,' in Intellect et imagination dans la Philosophie Médiévale / Intellect and Imagination in Medieval Philosophy / Intelecto e imaginação na Filosofia Medieval (Turnhout: Brepols, 2005), pp. 1113-29, whose arguments I partially resume here.

46 Pedro Hispano, Scientia, X, 6 (ed. Alonso, p. 382, 28-30): 'Intellectus primus omnia cognoscit, omnia distinguit, omnia regit, atque movet nec ab eorum contactu operis patitur debilitatem.' The first intelligence or the creator of all things has a multitude of names in the Scientia, but Deus is never used. For some examples, Hasse, Avicenna's De anima, p. 219, n. 784, and a more complete list in Meirinhos, Metafísica do homem, p. 132, n. 277.

47 Pedro Hispano, Scientia, X, 7 (ed. Alonso, pp. 379, 27-380, 4): 'Est igitur intellectus agens virtus anime intellective intelligibiles species in intellectu possibili a virtutibus sensitivis susceptas lucis sue illustratione illuminans, a materialibus ac accidentalibus appenditiis eas detegens, ad sue essentie puritatem redigens et de potentia ad intelligendi actum perducens.'

48 Pedro Hispano, Scientia, X, 7 (ed. Alonso, p. 380, 6-12): 'Hec igitur virtus pure lucis fulgore precellens ad summe cause cognitionem extendi nata est, ad eius splendorem supremum dirigens aspectum. Cum enim intellectiva anima notitie eius capax sit, in cuius solis aspectu supremum suscipit complementum, neque in creaturarum conprehensione eius sistit industria, cum sua excellencia super omnia sublimetur.' Petrus accepts the Avicennian doctrine of the double face of the soul (Liber de anima, I.5, ed. Van Riet, vol. I, pp. 94-95) that was particularly influential in Franciscan philosophy; J. Rohmer, 'Sur la doctrine franciscaine de la double face de l'âme,' Archives d'histoire doctrinale et littéraire du Moyen Âge 2 (1927), pp. 73-77. See also John of La Rochelle, Summa de anima, I, c. 45 (ed. Bougerol, pp. 146-47). 
soul their nature and the archetypes of things. ${ }^{49}$ It is because the agent intellect is completely devoid of mixture with material things, and also contemplates higher realities that Petrus defines the intellectual soul as 'inmortalis, separabilis, perpetua, inmixta, ${ }^{50}$ that evokes Aristotle's description of the agent intellect. ${ }^{51}$ The theory of the threefold agent intellect also intends to be a solution for this description, while making the agent intellect a faculty proper to each individual human intellect.

In discussing the separate agent intelligence, Petrus' theory is akin to Avicenna's, but he subscribes neither to the exclusivity of its action, nor to the theses of direct illumination of the forms in the imagination for their actualization in the possible intellect. A small passage can show how Petrus, without quoting any author, presents and rejects their position and, in the same movement, stresses his own position. We must understand the three parts of the argument, first expounding an explanation (estimatur [...] unde dicitur [...]), but concluding with a remark (verum [...]) that counters the Avicennian theory of the separate intelligence, admitting the reception of other intelligible objects in human souls:

It is believed (estimatur) [by someone, not mentioned] that the soul's agent substance is identical with the intelligence of the last order. That is why it is said (unde dicitur) that a separate simple substance actualizes the intelligible forms, communicating them to the intellect and illuminating it with its irradiation, to achieve the intellection. However what is true (verum) is that the intellectual soul receives intelligible impressions from all creatures as well sometimes from both the first and second intelligences. ${ }^{52}$

Stressing again the differences between these three agents of human intellection, Petrus claims, albeit briefly, that the agent intellect can perform the acts of cognition and of thinking in the human soul by its own power. It is the function of the agent intellect to illuminate the possible intellect, which it can do by way of its own light,

49 Pedro Hispano, Scientia, X, 7 (ed. Alonso, p. 380, 16-24): 'Eadem vero virtus substantias separatas conprehendere nata est, quibus ipsa anima est conformis. (...) Similiter separate substantie suam naturam et rerum exemplaria anime per huius virtutis officium representant.'

50 Pedro Hispano, Scientia, X, 7 (ed. Alonso, p. 383, 25-26).

51 Aristotle, De anima III.5 (403a17), trans. vetus: 'Et hic intellectus separatus, immixtus et inpassibilis, substantia actu est;' trans. arabo-latina: 'Et iste intellectus etiam est abstractus, non mixtus neque passibilis, et est in sua substantia actio;' Averroes, Commenatrium magnum in Aristotelis De anima, ed. Crawford, p. 440.

52 Pedro Hispano, Scientia, X, 7 (ed. Alonso, pp. 386-87): 'Estimatur autem illa agens substantia intelligentia ultimi et infimi ordinis, quae animae intellectivae intimior ipsi intelligibilia sua illustratione revelat ut lux ad colores ad formas intelligibiles comparata. Unde dicitur substantia simplex separata formas intelligibiles ad intelligenda actum perducens, ipsas intellectui copulans et sua irradiatione ipsum illuminans, ut ad intelligendi penveniat complementum. Verum intellectiva a singulis craturis intelligibiles suscipit impressiones et quandoque ad infimas et a prima et a singulis intelligentiarum ordinibus influentias (...) suscipere iudicatur' (my emphasis). This text continues the one quoted in n. 44. 
together with that light which it draws from the first intelligence or the separate intelligence. ${ }^{53}$

The theory of the three agents of human intellection is in itself a doctrinal complex that seemingly eludes all historiographical labels, on account of its combination of a variety of sources that are hard to classify. In any case, it is neither 'Avicennized Augustinianism', nor does Petrus subscribe fully to Avicenna's theory of the agent separate intelligence, nor to the pure Augustinian theory of illumination, and above all, he does not quote any one of these sources.

\section{The Threefold Agent Intellect in the First Half of the 13th Century}

This tripartition of the agent intellect is to be distinguished from the tripartition of the intellective soul of Aristotelian origin which was made central by Alexander of Aphrodisias, who spoke of a material intellect, intellect in habitu, and agent intellect. ${ }^{54}$ Petrus' tripartition concerns the agent intellect only, not the intellect itself.

Petrus Hispanus brings into his discussion the actual possibility of human knowledge and thinking. And his way of expressing himself suggests that the threefold agent intellect was more or less familiar to his readers. Its general thrust seems to respond to at least three concerns also present in other philosophical doctrines on the soul discussed during the first half of the 13th century: 1. the philosophical tendency to accept the spontaneity of the human soul concerning knowledge and action implies the presence of an agent intellect proper to the individual person, and thus rejects the idea that intellect or any of its parts is common to all mankind; 2. acknowledging the necessity of an assisting or higher illumination that makes knowledge and even contemplation of the transcendent possible is a consequence of the conception of the human intellect as created and is related to the abstraction of sensible forms,

53 Pedro Hispano, Scientia, X, 6 (ed. Alonso, p. 380, 24-28): 'Huius vero virtutis industria inpressiones a summa causa et separatis substantiis susceptas possibili intellectui reddit, a quo ad virtutes sensibiles interiores et ab hiis in exteriores secundum ordinem derivantur.'

54 Alexander Aphrodisias, On the intellect, in Two Aristotelian Commentators on the Intellect, trans. F.M. Schroeder and R.B. Todd (Toronto: PIMS, 1990), pp. 46-48: 'Intellect, according to Aristotle, is threefold. One type is material intellect (...). Different again is [the intellect] once it is engaged in thinking and is in a state of possessing thought and is capable of acquiring by its own capacity the forms of objects of thought (...). The third intellect, on the other hand, in addition to the two already described, is the productive intellect through which the material intellect enters a state of possession, and this productive intellect is analogous, as Aristotle says, to light;' Latin translation in Alexander Aphrodisiensis, Liber de intellectu et intellecto, ed. Gabriel Théry (Paris: Vrin, 1926), pp. 74-75: 'Dixit Alexander, quod intellectus apud Aristotelem est tribus modis: unus est intellectus materialis (...). Sed intellectus habet alium gradum, cum scilicet intelligit et habet habitum. (...) Tertius autem est praeter duos praedictos, qui est intelligentia agens, per quam intellectus materialis fit, ut habeat habitum.' 
which prevents the soul from elevating by its own powers to this higher order of knowledge; 3. as the soul places the human being at the confluence of the higher and lower realities, the intellect, through its agent capacity, is the nexus that can achieve its perfect state by knowledge, and then, by the free action that depends on knowledge, can ascend to the origin of all things.

Since the author claims to have written the Scientia by compilation (componendum), that is, taking its positions from different sources, let us then attempt to trace the origins of this particular explanation of the agent intellect in his Latin predecessors. It is absent in works of more decisive Aristotelian or Avicennian influence, such as Gundassalinus' Tractatus de anima or John Blund's Tractatus de anima. Things tend to change when we approach texts on the soul written around 1220 and 1230.

In the anonymous De potentiis animae et objectis written about 1230, we find the assertion that there is an agent intellect for each and every person, and that this intellect is part of the substance of the soul, rejecting simultaneously that the agent intellect is any sort of separate substance that radiates over the possible intellect. For the anonymous author, the human intellect has in itself the capacity to know material things. However, the illumination by a higher entity is also considered necessary for the knowledge of intelligible realities, which the intellect is by itself incapable of reaching. ${ }^{55}$

In this position, which responds to the assertions of some anonymous philosophers who defended the separateness of the agent intellect, we can find the same three elements that Petrus would develop: the autonomous individuality of the human agent intellect, the need for illumination by the higher created substances (the intelligences) in order to acquire full-blown knowledge of them, and the indispensability of divine light to attaining understanding of the divine essence. This explanation accommodates the theory of the separate agent intelligence, with a limited function, but denies its intervention either in the knowledge of lesser realities, for which the human intellect suffices, or in the direct contemplation of the divine essence.

We find a similar position in the De anima et de potenciis eius, from about 1225 , which the editor, René-Antoine Gauthier, considered to be a source of the aforementioned treatise. Here the interest of the anonymous author is to distinguish between

55 De potentiis animae et objectis, ed. Daniel A. Callus, 'The Powers of the Soul. An Early Unpublished Text,' Recherches de Theólogie Ancienne et Médiévale 19 (1952), pp. 131-70, cf. p. 156: 'Fuerunt tamen quidam philosophorum qui dixerunt intellectum agentem esse substantiam separatam a substantia anime, et per irradiationem sui super possibilem fieri intellectum possibilem in effectu. Sed oportet intelligere quod non requiritur talis irradiatio intellectus agentis et separati super intellectum possibilem, nisi quantum ad quedam intelligibilia ad que non potest intellectus ex se, sicut sunt ea que de divina essentia intelliguntur divino modo, et quibus humana ratio repugnare videtur. Et preter hec sunt alia quibus intelligendis indiget intelligentia separata, que licet possit comprehendere, non tamen ita ad plenum quemadmodum intelligentie que sunt supra ipsam, sicut accidit de ordinibus angelorum et de custodia eorum et de potestate super semina rerum corporalium.' 
the possible intellect and the agent intellect, exactly as Petrus will do later. The two proper acts of the agent intellect are 1. to abstract the species from the phantasms, and 2. to organize the abstracted species in the possible intellect. Such a claim of the intellect's cognitive autonomy demands explicit rejection of Avicenna's theory, which placed the agent intellect outside the soul. For the anonymous author there is no doubt: the agent intellect is a power of the soul, it performs intellection when it wants - for the phantasms are always present to the soul - and the intellect that abstracts the species from them is a power of the soul. ${ }^{56}$ For the anonymous author the agent human intellect is in fact twofold.

These two brief works on the soul (De potentiis animae et objectis, c.1230; De anima et de potenciis eius, c.1225) present a clear assertion of the individual nature of the agent intellect, which possesses an inherent power of abstracting intelligible forms. According to Bernardo Bazán, this defence of the autonomous nature of the active intellect cannot be considered as a side product of an erroneous reading of Averroes, ${ }^{57}$ as some scholars supposed, but instead is an original contribution of Latin philosophy to the Aristotelian tradition in the first half of the 13th century. ${ }^{58}$ Bazán also stresses that Franciscan theologians 'embraced the thesis of the agent intellect as a faculty of the soul, ${ }^{59}$ and among other texts of the first half of the 13th century he quotes the Commentary on the De anima attributed to Petrus Hispanus, ${ }^{60}$ but not the Scientia.

56 De anima et de potenciis eius, ed. René-Antoine Gauthier, 'Le traité De anima et de potentiis eius d'un maître ès arts (vers 1225). Introduction et texte,' Revue des Sciences Philosophiques et Théologiques 66 (1982), pp. 3-55, see pp. 51, 446-52, 463: '<De intellectu agente > Est autem talis comparatio agentis ad possibilem qualis est comparatio lucis ad uisum. Sicut enim lux facit resultare speciem coloris de ipso colorato in oculum, ita intellectus agens abstrahit species a fantasmatibus, quas preparauit ei intellectus materialis, et facit eas quodam modo resultare in intellectu possibili. Vnde duo sunt actus intellectus agentis: unus est abstrahere species a fantasmatibus, alius est species abstractas ordinare in intellectu possibili. / Et in hoc erravit Avicenna, quia posuit intellectum agentem separatum ab anima, puto intelligenciam siue angelum, sicut sol est separatus a uisu. Set non est dubium hunc intellectum esse potenciam anime; cum in potestate anime sit intelligere quando uult: ex hoc enim sequitur quod et fantasmata sunt semper ei presentia, et intellectus agens qui abstrahit species a fantasmatibus est copulatus anime sicut potencia eius. Quod patet in visu per contrarium, quia non videmus album quandocunque volumos, quia vel lux semper non est presens, vel si lux est aliquando presens, ipsum album poterit esse absens. / Hec de intellectu agente dicta sunt, scilicet quod duo sunt actus eius et quod ipse est potencia' (my emphasis).

57 That was the thesis of D. Salmán who introduced the label 'First Averroism' in a pair of studies on John of La Rochelle's theory of the intellect: D. Salman, 'Note sur la première influence d'Averroes,' Revue neoscolastique de philosophie 40 (1937), pp. 203-12; idem, 'Jean de la Rochelle et l'Averroïsme latin,' Archives d'histoire doctrinale et littéraire du Moyen Âge 16 (1947-48), pp. $133-44$.

58 So it cannot be labeled as 'First Averroism'; see Bernardo Carlos Bazán, 'Was There Ever a "First Averroism”?', in Geistesleben im 13. Jahrhundert, ed. J. A. Aertsen and A. Speer (Berlin; New York: De Gruyter, 2000), pp. 31-53.

59 Ibid., p. 37.

60 Ibid., p. 43. 
In De potentiis animae et objectis and in De anima et de potenciis eius two questions are left in suspension: how to understand the separate agent intelligence, and how to account for the fact that the human intellect is simultaneously agent to the abstraction of the intelligibles of lower things, and receptive of intelligibles already existent?

John of La Rochelle will provide an answer to both problems, which leads us directly to Petrus Hispanus and the theory of the 'threefold agent intellect' in the human soul. In the Tractatus de divisione multiplici potentiarum animae (c.1233-35), ${ }^{61}$ while undertaking to demonstrate the existence of the agent intellect, he relies on Avicenna to show that the intelligible requires that a power already in act make the potential forms become actualized in an act of intellection. For that, there must necessarily be in us an agent intellect endowed with this active power, whose activity is described as illumination. ${ }^{62}$ Hence a problem emerges: is that agent intellect separate from the soul or is it a power of the soul? If it is separate, is it a created intelligence, like an angel? Or is it the non-created intelligence, that is, God? ${ }^{63}$

John of La Rochelle's answer is based on a series of arguments that depart from Avicenna's authority to affirm the necessary existence of the agent intellect. But the reply to these questions implies the construction of an eclectic position on the nature of the agent intellect, which appeals to different authorities, explicitly quoted. First of all, the agent intellect is the uncreated intelligence, or God, under the authority of Augustine's Soliloquia, showing that God is, God has intellection, and God brings about intellection of other things; and this last reason shows that it is agent intellect, whose illumination (according to the authority of the Gospel of John) is not appropriate to the understanding of the sensibles, but rather of the intelligibles. ${ }^{64}$ The agent intellect too is the created intelligence or angel, in this case relying on the authority of Dionysus and other authors on the manifestatores (or the angels), as they are light and

61 John of La Rochelle, Tractatus de divisione multiplici potentiarum animae, ed. Pierre MichaudQuantin (Paris: Vrin, 1964), see II, ch. 19 'De intellectu agente, opponendo primo,' ch. 20 'De responsione et obiecta,' pp. 88-91. In the Summa de anima, dated around 1235-36, John includes the same chapters. See also John of La Rochelle, Summa de anima, ed. Jacques-Guy Bougerol (Paris: Vrin, 1995), ch. 116 'Vtrum intellectus agens sit separatus:' pp. 277, 27-280, 75. This same section on the agent intellect is discussed in Denise Ryan, An Examination of a Thirteenth-Century Treatise on the Mind/ Body Dichotomy: Jean de La Rochelle on the Soul and its Powers, PhD thesis (Maynooth: National University of Ireland, 2010), pp. 227-31, stressing its dependence on Avicenna.

62 For our period and Avicenna's influence on Augustinian intellectual illumination theory, see Lydia Schumacher, Divine Illumination: The History and Future of Augustine's Theory of Knowledge (Oxford: Wiley-Blackwell, 2011) pp. 85-109 ('Divine Illumination in Transition (AD 1109-1257)'). 63 John of La Rochelle, Tractatus de divisione multiplici potentiarum animae, pp. 88-89: 'De intellectu autem agente, quoniam sit, sic probatur ab Auicenna (...) necessario igitur in nobis est agens <intel>lectus.' See also Summa de anima, ch. 115, p. 277

64 John of La Rochelle, Tractatus de divisione multiplici potentiarum animae, p. 89, 668-67: 'Quod vero sit intelligentia increata, que est Deus, sic probatur (...).' See also Summa de anima, ch. 116, p. 277, 4-13. 
a proportionate light to the human intellect, so they can also be an agent intellect. ${ }^{65}$ And finally, the agent intellect is not a separate faculty of the human soul, on the authority of Augustine (in fact pseudo-Augustine, since the quoted text is from the $D e$ spiritu et anima), as in the human soul there is a light imprinted by creation for the knowledge of intelligible realities; and that light is precisely the agent intellect, and as such is not separated from the substance of the soul. ${ }^{66}$

Supported by these authorities, John of La Rochelle is then in a position to answer the question of whether or not the agent intellect is separable. ${ }^{67}$ His answer is guided by Augustine (once again, the De spiritu et anima) and will accommodate all three modes of the agent intellect as they actualize all kinds of intelligibles: those that are beyond it (God), those that are above it (the angel), those that are internal to it (the soul itself), and those that are below it (sensible things). ${ }^{68}$

And to grasp these intelligibles, the human intellect is informed by different active capacities: God's illumination is necessary to understand the divine essence and the persons of the Trinity, 'and of those intelligibles that exceed the human intellect, God is said to be entirely agent intellect; ${ }^{69}$ the angel's illumination is necessary to understand things that are above the soul (the angelic essence, powers, orders and activities), and in this case 'the angel can be said to be the agent intellect, as it instructs the human intellect; ${ }^{970}$ an innate light is sufficient for the soul to under-

65 John of La Rochelle, Tractatus de divisione multiplici potentiarum animae, p. 89, 678-93: 'Quod autem intellectus agens sit intelligentia creata, que est angelus, probatur (...).' See also Summa de anima, p. 278.

66 John of La Rochelle, Tractatus de divisione multiplici potentiarum animae, p. 90, 694-704: 'Quod autem intellectus agens non sit separatus a substantia anime, immo sit quedam differentia uirtutis partis intellectiue probatur per Psalmistam (...).' See also Summa de anima, p. 278.

67 John of La Rochelle, Tractatus de divisione multiplici potentiarum animae, chap. XX: 'De responsione ad obiecta,' pp. 90 -91; see also Summa de anima, pp. 278-79.

68 Dag Hasse, despite being more interested in the theory of the Separate Intelligence, discussing apprehension of different kinds of intelligible object, noted briefly the relation between the $D e$ anima et potentiis eius, the De potentiis animae et obiectis, John's three agents of the souls, and the Summa fratris Alexandri; see Hasse, Avicenna's De anima, pp. 201-2.

69 John of La Rochelle, Tractatus de divisione multiplici potentiarum animae, p. 90, 710 - 19: ‘(...) dicendum ergo quod ad intelligenda ea, que sunt supra se, sicut sunt ea que de diuina essentia et trinitate personarum intelliguntur diuino modo, indiget anima irradiatione ab ipsa luce prime ueritatis eterne super supremam uim suipsius que dicitur mens uel intelligencia, de qua dicit Augustinus in libro De spiritu et anima quod, nulla interposita natura formatur ab ipsa prima ueritate. Respectu igitur huius summe veritatis [cf. Summa: uirtutis summe] et respectu horum intelligibilium que excedunt humanum intellectum omnino, dicitur Deus agens [cf. Summa: intellectus agens] et huiusmodi illuminatio est gratie infusio ad contemplanda diuina.' See also Summa de anima, p. 278.

70 John of La Rochelle, Tractatus de divisione multiplici potentiarum animae, p. 90, 719-24: 'Ad cognoscenda uero ea, que sunt iuxta se, ut sunt angelice essentie, uirtutes et ordines et operationes, indiget anima reuelatione angelica [add. Summa: siue instructione], et in hac operatione [cf. Summa: comparatione] intellectus angelicus posset dici agens respectu intellectus humani, inquantum instruens, sed hoc non respicit supremam faciem intellectus humani que est ad eterna et increata, sed uirtutem inferiorem.' See also Summa de anima, p. 278. 
stand itself, its faculties, habitus, science and virtues (for this purpose, the soul does not require an external agent, and so it is able by itself to know that it is); ${ }^{71}$ finally, the human agent intellect knows the things that are below itself, and in order to understand these things, the illumination of a separate substance is not necessary, 'sufficing the inner light, which is the agent intellect, supreme faculty of the soul. ${ }^{72}$ This explanation is not a standard one, and Leonard Bowman considered 'ambiguous' this use of the expression agent intellect 'to refer to anything that simply influences the soul in its act of knowing. ${ }^{73}$

John of La Rochelle's explanation of the different kinds of intelligibles, and of the aids the soul needs to grasp them, provides the sources that allow us to understand how he built this tentative solution (solutio sine praiuditio). The Latin authorities are especially relevant here, above all, Augustine or pseudo-Augustine. ${ }^{74}$ In this way, knowledge intimately binds four levels: 1 . an intrinsic abstractive power of the intelligible; 2 . the knowledge of the soul as present to itself; 3 . the separate agent intelligence; 4. the direct illumination by God. This is precisely the position held by Petrus Hispanus, except that it replaces the angel with the separate agent intelligences and omits the Augustinian sources, relying mostly on Avicennian terminology; yet paying heed to the observation of John of La Rochelle when he warns that the reception of this light does not correspond to the superior face of the soul. In fact, the latter is turned towards what is eternal, and, in the end, the separate intelligence (or the angel) is still a creature. It is this cautionary remark that will lead Petrus to constantly introduce restrictions on the theory of the separate agent intelligence, always placing first intelligence above it, which should be indeed the ultimate end for human contemplation, and not attributing to the separate intelligence any special role in the abstraction of the sensible forms stored in imagination.

71 John of La Rochelle, Tractatus de divisione multiplici potentiarum animae, p. 90, 727-91, 731: 'Ad cognoscendum uero ea que sunt intra animam, ut est ipsa anima et potentie ipsius et habitus scientie et uirtutes, non indiget anima lumine extrinseco; sed lumine innato cognoscit se esse, se posse raciocinari, sentire, se scire aliquid uel ignorare, iustam uel iniustam esse, per conuersionem ad se.' See also Summa de anima, p. 278.

72 John of La Rochelle, Tractatus de divisione multiplici potentiarum animae, p. 91, 732-39: 'Ad cognoscenda uero ea que sunt infra se, non indiget similiter lumine intelligentie que sit extra se. Cum enim natura intellectus humani superior sit rebus corporalibus, superior etiam incorporalibus que sunt in ipsa ut in subiecto, utpote potentie, habitus, disposiciones et affectiones, ideo ad hec comprehendenda non est necessaria illuminacio substantie separate, sed sufficit lumen internum quod est intellectus agens, uis anime suprema, de quo fit hic sermo.' See also Summa de anima, p. 279. 73 Leonard J. Bowman, 'The Development of the Doctrine of the Agent Intellect in the Franciscan School of the Thirteenth Century,' The Modern Schoolman 50 (1973), pp. 251-79, esp. 256; for John of La Rochelle see pp. 255-57.

74 After another solution absent in the Summa de anima (Tractatus II, ch. 21: 'De alia solutione cum quadam additione') John presents the theory of Avicenna on how agent intellect illuminates sensible forms in imagination and acts upon possible intellect (Tractatus II, ch. 22: 'De operationibus intellectus agentis et possibilis;' Summa ch. 117: 'De operatione intellectus agentis'). 
John of La Rochelle discusses in detail the threefold agent intellect identifying the bunch of sources from which it was composed, as a new solution for some. As we have seen, the anonymous author of the De potentiis animae et objectis briefly presents the same theory. Daniel Callus demonstrates with the section on the intellect of the De potentiis that John depends on it. ${ }^{75}$ But it could be much more plausible that the anonymous' short version is a summary of John's detailed presentation of the theory in both his works. In this case he must be credited for being not only the source of Petrus Hispanus but also for the creation of the theory itself, which was probably summarized in the De potentiis animae et objectis and developed with more systematic consequences in the Scientia libri de anima.

\section{Remnants of an Unfinished Debate and Some Hypotheses}

This explanation of the agent intellect echoes in the Summa fratris Alexandri, which to some extent summarizes and rephrases John of La Rochelle's discussion in his Summa de anima on the agent intellect in the human soul. ${ }^{76}$ The question on the cognitive rational power ${ }^{77}$ presents, in its two first members, three main divisions of the soul's intellectual powers: pseudo-Augustine's De anima et spiritu, John Damascene's, Aristotle's. ${ }^{78}$ Lexical issues have some importance, namely the equivalences or distinctions between intellectus, mens, ratio. The Aristotelian-Alexandrian division - material, possible, and agent intellect - is received so as to explain the origin of the intelligible forms in the intellect, through abstraction from sensible images. ${ }^{79} \mathrm{Com}$ bining Aristotle - assimilated to Avicenna - and Augustine, abstraction and illumination are two possible ways for the soul to access, respectively, the forms present in material beings and the pure intelligible forms. Having established that the possible

75 Callus, 'The Powers of the Soul,' pp. 140 - 43. Bougerol added that the Summa de anima section on the internal senses quotes the De potenciis twelve times (Summa de anima, ed. Bougerol, p. 32). The question deserves another look as to ascertain who quotes whom, as it is not implausible that John of La Rochelle's work antedates the De potentiis animae et objectis.

76 Lydia Schumacher, 'The De anima Tradition in Early Franciscan Thought: A Case Study in Avicenna's Reception,' in The Summa Halensis: Sources and Context, ed. Lydia Schumacher (Berlin; Boston: De Gruyter, 2020), pp. 155-69.

77 SH II, In4, Tr1, S2, Q3, Ti1, pp. 446-64: 'De vi rationale cognitive.'

78 SH II, Q3, Ti1, M1-2, pp. 446-59. See Margaret M. Curtin, 'The Intellectus Agens in the Summa of Alexander of Hales,' Franciscan Studies 5 (1945), pp. 418-33.

79 SH II, In4, Tr1, S2, Q3, Ti1, M1, C1 (n. 368), Solutio, pp. 447-48: '[Divisio] Augustini [sc. ratio, intellectus, intelligentia] accipitur secundum differentias formarum intellibilium simplicium, illa vero quae est Philosophi accipitur secundum modum proveniendi ad cognitionem illarum formarum intelligibilium quae veniunt ad intellectum per abstractionem a phantasmate sensibili. (...) divisio Philosophi, quae est secundum triplicem intellectum, materialem, possibilem et agentem, respicit proprie formas intelligibiles abstractibiles a conditionis sensibilibus.' 
and the agent intellect 'sunt duae differentiae in anima rationali,' the Summa is more interested in ascertaining whether this agent intellect can grasp or attain the intelligibles above the soul, or if it is a power above the intellect illuminating it (and thus in itself separate). For the Summist, the intellect is in act not because it knows everything from the beginning ('non quia [...] omnes formas a principio intelligit'), but rather because it is illuminated by the first agent (' $a b$ agente primo illuminatur'). This illumination does not encompass all intelligible forms, but only some of them ('quarundam'), and, as the agent intellect is illuminated by the first agent, the same mode illuminates the possible intellect. ${ }^{80}$ Therefore, the mute and modified evocation of John of La Rochelle is enough to sustain by exclusion that a separate agent is not necessary to know all the intelligibles, as the soul itself can actualize and thus know forms received by abstraction; the higher help is needed only for those intelligible objects above the soul. ${ }^{81}$ An external agent of the human soul is not ruled out, as it is necessary to access intelligible forms not received through the internal senses.

In the Summa Halensis, the former philosophical explanation on the agent intellect of the human soul, ${ }^{82}$ composed by John of La Rochelle under the authority of Aristotle, Augustine, Pseudo-Dyonisius, and Scripture, is used only briefly, without mentioning all the three agents of the soul, mostly to confirm that the Aristotelian division of the intellect does not prevent access to all kinds of intelligibles. The human agent intellect grants the reception of forms by abstraction and by illumination from a higher intelligence, thus ensuring that human reason has the power to achieve supernatural knowledge trough a natural and individual faculty.

In a much more elaborate and extended way, this is exactly what Petrus Hispanus tries to do with his Summa philosophica de anima. In the Scientia, the threefold human agent intellect and the three kinds of intelligibles pervade the discussion of the rational soul. His full use of John's pluralistic interpretation of the human agent intellect is combined with a more Avicennian theory regarding the role of the internal senses and of the possible intellect - but at the same time limiting the scope of the Avicennian theory of the separate intelligence, which is admitted simply as one of the agents in the human intellect.

Further research is needed to verify how much this pluralistic theory of the agent intellect spread in the first half of the 13th century, when and how it faded away. ${ }^{83}$ To

80 SH II, In4, Tr1, S2, Q3, Ti1 (n. 372), p. 452.

81 See the interpretation and discussions about this piece of the Summa in Hasse, Avicenna's De anima in the Latin West, pp. 217-18, and Schumacher, 'The De anima Tradition in Early Franciscan Thought,' pp. 165-68.

82 The Summa names as 'investigatio philosophica' the study of the soul as a 'tabula nuda', that is to say, as regards Aristotelian abstraction from senses and the workings of the possible intellect. SH II, In4, Tr1, S2, Q3, Ti1, C2 (n. 369), p. 449.

83 Looking at the dossier presented by Étienne Gilson, the authors after John of La Rochelle do not seem to share his pluralistic theory of the agent intellect, limiting themselves to the variant identify- 
this day, it was only traced in a summary form in the De potentiis animae et objectis, in a fully-elaborated form in John's works, and integrated in a systematic theory of the faculties of the soul in Petrus Hispanus' Scientia libri de anima.

In his De anima, c.1240, William of Auvergne rejects both the agent intellect as a part of the soul and as a separate intelligence, thus rejecting the fundamentals of John and Petrus' threefold theory, which is not directly addressed. ${ }^{84}$ The Anonymous of Gauthier, who commented the De anima in Paris c.1246-47, seems to be already a distant echo of this discussion. ${ }^{85}$ On De anima III, 5, this master raises the question 'quid sit intellectus agens,' presenting opinions of non-identified authors (quidam). One of them is the position of 'magni clerici et antiqui, ${ }^{86}$ who identify the agent intellect with the 'Prima causa', but the master proposes arguments that contradict this possibility. ${ }^{87}$ As a second argument to show that agent and possible intellect are the same in substance but distinguishable by reason, he recalls the opinion of those who say that the intellect is possible as it is inclined towards phantasy, and agent as 'intelligit substancias simplices et spirituales, ut Primum et intelligencias, quod secundum se aptus natus ad intelligendum eas (as it understands simple and spiritual substances, such as the First and intelligence, because it is apt naturally to understand them of its own accord). ${ }^{88}$ This opinion does not deserve any further discussion and ap-

ing the agent intellect with God, under the authority of Augustine and Avicenna, that defines as such the 'Avicennized Augustinianism'. See Gilson, 'Pourquoi S. Thomas,' pp. 89-111, and Gilson, 'Roger Marston,' p. 42, where a provisional list of its supporters is offered: William of Auvergne and Adam of Marisco, Roger Bacon, John Peckham, Roger Marston, Vital du Four. I thank Lydia Schumacher for pointing out to me that the threefold agent intellect theory is not traceable to theologians such as Hugh of St. Cher, Roland of Cremona, William of Auxerre, or even Alexander of Hales. Philip the Chancellor too discusses the separability of the agent intellect in the traditional way. See Philip the Chancellor, Summa de bono, ed. Nikolaus Wicki, 2 vols (Bern: Francke, 1985), I, pp. 193, 232, 270, 437, and Salman, 'Jean de La Rochelle et les débuts de l'Averroisme Latin,' pp. 139-42 on how John took from Philip the discussion on ratio.

84 See William of Auvergne's De anima, composed c.1240, part III of the Magisterium divinale ac sapientiale, in Guilielmi Alverni Opera Omnia, 2 vols (Paris: Apud Joannem Lacaille, 1674, repr. Frankfurt am Main: Minerva, 1963), which rejects the agent intellect theory in VII, 3-5. See also William of Auverge, De l'âme (VII, 1-9), intro. and trans. Jean-Baptiste Brenet (Paris: Vrin, 1998), pp. 98-120; William of Auvergne, The soul, intro. and trans. Roland J. Teske (Milwaukee: Marquette University Press, 2000), pp. 428-43. Brenet discusses in detail William's position against the agent intellect theories (pp. 14-20).

85 Anonymi, magistri artium (c.1245-50), Lectura in librum de anima a quodam discipulo reportata (Ms. Roma Naz. V. E. 828), ed. Renatus A. Gauthier, Specilegium Bonaventurianum, 24 (Grotaferrata, Rome: Colegii S. Bonaventurae ad Claras Aquas, 1985).

86 On the meaning of 'antiqui' as applied by authors such as Albert the Great, Thomas Aquinas or Roger Bacon and others to the precedent generation of 13th-century Parisian theologians (roughly active from 1200 to 1240), see Marie-Dominique Chenu, 'Notes de lexicographie philosophique médiévale. Antiqui, moderni,' Revue des sciences philosophiques et théologiques 17:1 (1928), pp. 82-94, esp. pp. $86-87$.

87 Lectura in librum de anima a quodam discipulo reportata, pp. 468, 264-469, 293.

88 Lectura in librum de anima a quodam discipulo reportata, pp. 470, 330-471. 
pears only as secondary support for a very different discussion than the one engaged in by John, the Summa Halensis or Petrus. Other literal or question commentaries on the De anima would ignore the triple nature of the agent intellect once proposed by John of La Rochelle and seconded by Petrus Hispanus. The association of the human agent intellect to a higher illumination does not disappear at all, even when interpreting Aristotle. According to Gilson, Thomas Aquinas was the first to explain that the created agent intellect is sufficient to generate human knowledge, thus avoiding Avicennism and Augustinian illumination. ${ }^{89}$ In any case, for Thomas the action of the human agent intellect is a 'kind of participation in intellectual light by separate substances,' making potentially intelligible forms actually intelligible. ${ }^{90}$

A quick browse through the commentaries of many masters of arts on De anima shows how the discussion has shifted or is completely ignored. In the words of Siger of Brabant, when discussing the human intellect, as he proceeds as a philosopher, what he seeks is to understand the intention of the philosophers, rather than the truth of the problem. ${ }^{91}$ Other masters of arts from the 13th century share the same epistemic attitude, but invoke with a certain detachment, as a mere argument to discard, the possibility that the human soul can know separate intelligibles through the illumination of a separate intellect. The anonymous of Steenberghen (c.1273-77, Paris) denies that the 'Primum' can illuminate the possible intellect, as the intellect is not a separate substance, but rather a part of the soul itself. ${ }^{92}$ The Anonymous of Bazán (c.1272-77, Paris), relying on Aristotle, cannot accept that the intellect that

89 Gilson, 'Pourquoi Saint Thomas,' pp. 120-21.

90 Thomas Aquinas, Sententia libri de anima, ed. René-Antoine Gauthier, Opera Omnia, vol. 41-1, (Rome: Comissio Leonina; Paris: Vrin, 1984), III, 4: 'Quod intellectus agens non sit substantia separata,' p. 221, 164-65. English translation in Thomas Aquinas, A Commentary on Aristotle's De anima, trans. R. Pasnau (New Haven: Harvard University Press, 1999), p. 368. See also Summa Theologiae, I, q. 79, ar. 4 ('Utrum intellectus agens sit aliquid animae'): the solution contrasts the position of the philosophers and the one 'secundum documenta fidae nostrae' identifying the separate substance with God, the creator of the soul and the reason why 'the human soul participates in intellectual light (anima humana lumen intellectual participat)'. A parallel discussion is found in Aquinas' Quaestiones disputatae de anima, ed. B. Bazán, Opera Omnia, vol. 24-1 (Rome: Comissio Leonina; Paris: Vrin, 1996) ar. 5 ('Utrum intellectus agens sit unus et separatus'), Solutio: the agent intellect proper to the individual soul abstracts the phantasms from their material conditions; thence, it is like a power participating in a superior substance, God 'quasi quaedam virtus participata ex aliqua substantia superiori, scilicet Deo.' See also ibid., ad 6.

91 Siger of Brabant, De anima intellectiva, ch. VII, 101, in Siger de Brabant, Quaestiones in tertium de anima, De anima intellectiva, De aeternitate mundi, ed. Bernardo C. Bazán (Leuven: Peeters, 1972). For the preferability of faith when philosophical uncertainty subsists concerning the separability and multiplication of intellect, see ch. VII, 108. For the whole debate on the nature of the agent intellect and its noetic implications in a range of philosophers and theologians, see Antonio Petagine, Aristotelismo difficile: l'intelletto umano nella prospettiva di Alberto Magno, Tommaso d'Aquino e Sigieri di Brabante (Milan: Vita e Pensiero, 2004).

92 Quaestiones in De anima, III, 17, in Trois commentaires anonymes sur le traité de l'âme d'Aristote, eds. Maurice Giele, Fernand van Steenberghen, Bernard Bazán (Louvain: Publications Universitaires; Paris: Béatrice-Nauwelaerts, 1971), pp. 121-348, on p. 334, 33-42. 
animates a body can directly understand the separate substances, as it only knows through phantasms, and the separate substances are known only through their effects, never directly..$^{93}$ In the words of the Anonymous of Vennebusch (c.1250-60, Paris), ancient philosophers diversified their positions about the agent intellect following Aristotle and adapted their positions to the letter of Aristotle's texts; thus, it seems to him that it would be tedious to enumerate all the different positions (even so, many of them are presented in several sub-questions, despite their heavier focus on ancient, rather than contemporary, authors). ${ }^{94}$

While some authors, mostly theologians, seek to substantiate the possibility of access to the divine through natural cognitive faculties and contemplation, in the commentaries on Aristotle research tends to focus on textual interpretations and their consequences. Nonetheless, there were some strong reactions to the peripatetic reading of De anima, as is the case with some of the positions condemned in Paris in $1277 .^{95}$

In these commentaries and questions on the De anima of the second half of the 13th century, the separateness of the agent intellect and the nature of its intelligible objects continue to be the central concepts in the discussion of the possibility of accessing or forming true cognitions. But an eclectic approach is no longer in favor; the discussion is now centered on Aristotle's De anima III.5 and its interpreters, above all Averroes (as Avicenna is usually not recognized as a convincing Aristotelian commentator). In the last quarter of the 13th century, even among theologians, divine cognitive illumination theory would hardly survive philosophical criticism. ${ }^{96}$

Petrus Hispanus' work on the soul emerged in a different context, prior to the rise of commentaries in the Faculty of Arts. He is guided by a framework laid down by John of La Rochelle's Tractatus de divisione multiplici potentiarum animae and applied to a structure identical to Avicenna's Liber de anima. But, unlike John of La Rochelle's works, Petrus' Science of the Soul carefully eliminates any authority or references to authors and avoids any open discussion of different solutions for the same issue. This new reading justifies the title Scientia libri de anima or the Science of the book (of Avicenna) on the soul. ${ }^{97}$ John presented Avicenna's noetic psychology

93 Quaestiones in De anima, III, 14 (Trois commentaires, pp. 349-517), p. 495, 56-71.

94 Ein Anonymer Aristoteleskommentar des XIII. Jahrhunderts: Questiones in tres libros De anima (Admont, Stiftsbibliothek, cod. lat. 367), ed. Joachim Vennebusch (Paderborn: Ferdinand Schöningh, 1963), q. 67, pp. 290-303, here p. 297, 235-37; for a systematization of all the presented positions, see Vennebusch's introduction, pp. 64-65.

95 See also Bernardo Carlo Bazán, 'Conceptions on the Agent Intellect and the Limits of Metaphysics,' in Nach der Verurteilung von 1277: Philosophie und Theologie an der Universität von Paris im letzen Viertel des 13. Jahrhunderts. Studien und Texte, eds. Jan A. Aertsen, Kent Emery, and Andreas Speer, Miscellanea Mediaevalia, 28 (Berlin: De Gruyter, 2001), pp. 178-210.

96 Robert Pasnau, 'Henry of Ghent and the Twilight of Divine Illumination,' Review of Metaphysics 49 (1995), pp. 49-75; Schumacher, Divine Illumination, pp. 181-208.

97 'Scientia libri de anima' is the title of the work in Madrid's manuscript incipit (Scientia, Prologue, 3). The name given in the explicit is 'Liber de anima' (Ibid., ed. Alonso, p. 498). 
in the chapter devoted to the faculties of the soul according to the philosophers; ${ }^{98}$ likewise, Petrus took directly from Avicenna's Liber de anima a great deal of theories, without limiting himself to their positions, as is the case with the role of the agent intellect and the separate intelligence, and thus heavily reshaped their nature and functions in more Augustinian terms. ${ }^{99}$ Other non-Avicennian elements in Petrus come from John's psychological works, as is the case for several positions close to John Damascene. In his compendium, Petrus does not hesitate to intersperse faculties not discussed by Avicenna (free will, synderesis, etc.), because they seem to him indispensable to an integral treatment of the soul's actions, objects and organs. So the work has much more than Avicenna, not unlike John's Tractatus and Summa.

There are no reasons to identify Petrus Hispanus Portugalensis, whose academic cursus is described in the colophon of the Scientia libri de anima, with Petrus Juliani, the future Pope John XXI. Hence, there is no need to find a 'void period' in Juliani's career to date this work, as Gauthier seems to have done, dating it between 1250 and 1260 in Portugal. On the other hand, without a reasonable explanation, it is not plausible to suppose that the work was written in a moment where it would be perceived as outdated, in times when direct interest in Aristotelian texts and their rigorous interpretation, with the assistance of Averroes, was burgeoning - all this is practically absent from the Scientia. And there is no evidence that this work is somehow a reaction to these new tendencies, because they are not in fact opposed. More likely the work was written in the years immediately following the composition of John of La Rochelle's psychological works, published successively between 1232 and 1236. Hence, a date before 1240 seems much more plausible for the Scientia libri de anima, being a testimony to the immediate influence of the Franciscan philosophy and particularly of John of La Rochelle's works. If this hypothesis is correct, the theory of the threefold intellect had a very short life, surviving no more than a decade, fading away with the Avicennian interpretation of the intellect, no more accepted as a way to reconcile Aristotle and Augustine.

Read in this way, the Scientia libri de anima, whose author does not seem at first sight to bear any direct relation to the Franciscan environment, can be considered as a product of the Franciscan reception of Avicenna's thought and the construction of a theologically-informed philosophical psychology. Petrus accept other elements from many other origins, producing a systematic and integral exposition of the human soul, while assuming a philosophical perspective framed by a creationist position. The human being's highest active faculty leads by its ascent to divine contemplation,

98 John of La Rochelle, Tractatus de divisione multiplici potentiarum animae, pt. II, 1.1, pp. 70 - 103: 'De diuisione potentiarum anime secundum philosophos, specialiter secundum Auicennam.'

99 It is quite significant that Petrus, in the brief summary of the work included in the Prologue, highlights the research (hystoria) on the separate intellective soul ('et procedet hystoria circa animam intellectivam separatam et circa eius perpetuam et immortalem existenciam'), suggesting a special concern with the topic, but without making explicit the sources and to what degree he is modifying them. See Pedro Hispano, Scientia, Prologue, 5, 17-19. 
through an innate desire for God described by Petrus as theophilosia. The philosophical theory of the human intellect was recast so as to be consistent with this ultimate spiritual end, divinizing human beings both by knowledge and love. This is another clear consequence of the theory of the threefold agent intellect, as access to God is granted by its proper illumination, necessary to the fulfilment of this highest faculty. 